Mystetstvoznavstvo, vol. XV-XVI, pp. 115-124. [in [Piano works]. (Ed.).S. Pavlyshyn, Lviv, 113 p. [in Ukrainian].

3. Pavlyshyn, S. (2004). Persha ukrainska

Ukrainian].

6. Frait, O. (2013). Fortepianni albomy ta tsykly kompozytorka Stefaniia Turkevych-LisovskaLukiianovych [The first Ukrainian composer Stefania Turkeviи-Lisovsky Anastasia-Lukiyanovych]. Lviv: Bak, 160 p. [in Ukrainian].

4. Pavlyshyn, S. (2005). Peredmova [Introduction]. Turkevych S. Fortepianni tvory. Lviv, pp. 3-6. [in Ukrainian].

5. Turkevych, S. (2005). Fortepianni tvory ukrainskykh kompozytoriv dlia ditei: istoriia $i$ suchasnist: navchalno-metodychnyi posibnyk [Piano albums and cycles of Ukrainian composers for children: history and modernity: teacher's Guide]. Drohobych: Redaktsiino-vydavnychyi viddil Drohobytskoho derzhavnoho pedahohichnoho universytetu imeni Ivana Franka, 100 p. [in Ukrainian].

Стаття надійшла до редакції 13.04.2018

УДК $371.2: 378$

DOI:

Світлана Глікман, старший лаборант кафедри морських перевезень Азовський морський інститут Національного університету “Одеська морська академія”

\title{
МЕТОДИЧНЕ ЗАБЕЗПЕЧЕННЯ ФОРМУВАННЯ ПРОФЕСІЙНИХ ЯКОСТЕЙ МАЙБУТНІХ СУДНОВОДІїВ
}

У статті розкрито окремі аспекти використання тренінгів у формуванні професійних якостей майбутніх судноводїв, а саме: поетапність впливу на особистість курсантів; моделювання реакцій курсантів, спрямованих на досягнення конкретного результату; формування групи вмінь необхідних для виконання професійної діяльності та виявлення певних професійних якостей; визначення переваг обраних методів (мінілекиї, професійні ситуації, мозковий штурм, робота в малих групах та інше); послідовність видів навчальної діяльності; вимоги до ефективності використання тренінгів; приклади ситуаційних тренінгових завдань.

Ключові слова: майбутні судноводї; професійні якості; тренінг; формування.

Табл. 1. Лім. 8 .

Svitlana Hlikman, Senior Assistant of the Maritime Transportation Department Azov Maritime Institute of National University "Odesa Maritime Academy"

\section{THE METHODICAL PROVISION OF FORMING OF THE PROFESSIONAL QUALITIES OF FUTURE SHIP'S DRIVERS'}

There have been considered some aspects of using the trainings in the forming of professional qualities of the future ship's drivers in the article. So, according to the subject of the research there have been defined the definite changes which consist of three stages: the development of primary non-differentiated interest to the definite kind of activity, what is the main thing in the professional motivation; the forming of positive professional value orientations which give opportunity to create in the student's consciousness the ideal model of future special activity, that is the reference point in the professional self-development; an active formation of professional skills, necessary for practical activity. There have been determined the students' reactions directed to achievement of concrete result, namely ability to work independently without constant guidance, to take responsibility for own initiative, the readiness to find out problems and find ways of their solution, to use experience and knowledge for analysis of new (extreme) situations, ability to cooperate with other, to master new knowledge, to realize the constructive activity, to find out persistence and ingenuity, to analyze social situations and group processes. There have been defined the group of skills for execution of professional activity (actions as for ship and crew) and finding out definite the professional qualities (sociological, cognitological, psychological, synergetic, neocentric, ethical). There have been defined advantages of giving methods (mini-lectures, professional situations, brain storm, work in small group and others). In the article there have been displayed the sequence of kind of educational activity and requirements concerning the efficiency of using trainings. This cycle of teaching consists offour successive phases: actualization of personality experience, the analysis and thinking over this experience (reflection); comprehension of new knowledge, their theoretical generation (patterns, schemes); testing of new knowledge and individual using them in practice. There have been given the examples of situational training tasks.

Keywords: the future ship's drivers; the professional qualities; training, forming. 
співтовариство. Нині першочергова увага до системи функціонування морської вищої школи приділяється у зв'язку із імплементацією у законодавчу базу України поправок до Міжнародної конвенції 1978 року про підготовку і дипломування моряків та несення вахти (ПДНВ), які були прийняті у 2010 році на Дипломатичній конференції у м. Маніла (Філіппіни) і мають назву Манільських поправок [4]. Манільські поправки внесли значні зміни у сертифікати компетентностей для морських фахівців, зокрема, розширили і угочнили їх у світлі нових технологій, затвердили підвищені вимоги до підготовки моряків та визначили методи їх реалізації. Відповідно, приєднання України до Манільських поправок передбачає значні зміни у системі морської освіти, спрямовані на формування високого рівня компетентностей морських фахівців [8].

Судноводій - це людина, яка відповідає за безпеку плавання судна, збереження вантажу, що перевозиться або пасажирів, що забезпечує захист навколишнього середовища. Судноводій захищає інтереси судновласника i фрахтувальника, які, як правило, є різними юридичними особами і їх інтереси не завжди збігаються. Саме судноводій визначає мікроклімат в екіпажі і злагодженість його роботи, а тому він повинен мати особливий склад розуму і характеру, так як приймає рішення щодня, щогодини в реальному часі. Потрібна особлива психологічна підготовка, щоб жити у відокремленому колективі тривалий час і вміти знаходити спільну мову з усіма членами екіпажу.

Отже, підготовка здобувачів вищої освіти за спеціальністю “Судноводії” передбачає дотримання певного професійного стандарту. Професійні якості $€$ важливою складовою професійної компетентності та потребують цілеспрямованого формування.

Аналіз основних досліджень і публікацій. Дослідження проблем, пов'язаних з формуванням професійних якостей майбутніх судноводіїв, провели автори, які розглядали цей феномен у контексті організації освітнього процесу на основі компетентнісного та культурологічного підходів. Серед них близькими за предметом нашого дослідження є праці, в яких розглядаються: критерії та показники рівня готовності майбутніх морських офіцерів до професійної діяльності у полікультурному середовищі (Н. Бобришева); організація самостійної роботи майбутніх судноводіїв упроцесі вивчення вищої математики (О. Доброштан); особливості впровадження засад компетентнісного підходу у вищу професійну освіту фахівців морського транспорту (С. Сгорова); ціннісні орієнтації в системі професійно важливих якостей особистості судноводія рибопромислового флоту (О. Мітракова); педагогічні умови підготовки майбутніх суднових механіків у процесі вивчення професійноорієнтованих дисциплін (У. Ляшенко); педагогічні умови формування професійної компетентності судноводіїв упроцесі вивчення фахових дисциплін (I. Сокол); компетентнісний підхід до формування соціокультурної особистості майбутнього судноводія (Н. Слюсаренко); формування соціокультурної компетенції майбутніх судноводіїв у процесі вивчення професійно орієнтованих дисциплін (О. Фролова); теоретичні і методичні засади навчання фізики майбутніх фахівців морського та річкового транспорту(В. Чернявський); формування професійно значимих ціннісних орієнтацій курсантів для роботи в екстремальних ситуаціях (Т. Четверикова); структура професійної підготовки майбутніх судноводіїв у вищих морських навчальних закладах у контексті проблем формування інформативної культури (М. Шерман, О. Безбах) та ін.

У цих працях проаналізовано позитивні зрушення та характерні особливості змісту підготовки майбутніх судноводіїв відповідно до особистісно-гуманістичної парадигми освіти. Однак у загальному огляді наукових джерел не виявлено спеціальних праць, присвячених дослідженню професійних якостей майбутніх судноводіїв та їх формування в умовах вищого навчального закладу.

Мета статті - розкрити особливості використання тренінгів у формуванні професійних якостей майбутніх судноводіїв.

Виклад основного матеріалу дослідження 3 повним обгрунтуванням отриманих наукових результатів. Долучення сфери освіти до системи морських ресурсів потребує оновлення іiі змісту та вдосконалення методичного забезпечення. Упровадження тренінгових форм навчання майбутніх судноводіїв у процес фахової підготовки забезпечує формування професійних якостей та квазіпрофесійних навичок. Це твердження базується на розумінні тренінгу як процесу тренування та організації спеціального тренувального режиму [7, 245]. Згідно українському педагогічному словнику (за С.У. Гончаренко) тренування - це важлива складова професійного навчання, що має своїм завданням формування відповідних навичок та умінь, що здійснюється шляхом цілеспрямованого вправляння під керівництвом педагога- 
7інструктора на основі відповідних психологічних і методичних рекомендацій [2, 334]. Тренінг $є$ багатофункціональним методом передбачених змін психологічних феноменів людини, групи та організації з метою гармонізації професійного й особистісного буття людини [3].

Відносно предмету дослідження зміни відбуваються в три етапи:

Ieman-розвитокпочаткового недиференційованого інтересу до певного виду діяльності, що є головним у професійній мотивації. Сприяє цьому система бесід, дискусій, аналізу конкретних ситуацій, професійних симуляцій (рольових ігор).

II етап - формування позитивних професійних ціннісних орієнтацій, які дають змогу побудувати у свідомості курсанта ідеальну модель майбутньої фахової діяльності, що слугує орієнтиром у професійному саморозвитку. Реалізація цих завдань відбувається через систему активних методів навчання, провідними серед яких $є$ ігри зі спеціальності.

III eman - активне формування професійних умінь, необхідних для практичної діяльності. Воно здійснюється у процесі розроблення та реалізації навчальних проектів у змодельованих та реальних умовах конкретних ситуацій і вимагає від курсантів вияву самостійності, ініціативності, творчого підходу, наполегливості тощо. Сприяють вирішенню цього завдання комплексні ділові ігри та тренінги, які інтегрують зміст кількох спеціальних дисциплін.

Однією з відмінностей тренінгів відінших типів професійного навчання $є$ можливість концентрації в невеликому проміжку часу і простору елементів професійної діяльності, які каталізують процеси такої трансформації та моделювання реакцій, спрямованих на досягнення конкретного результату. Серед таких реакцій: здатність працювати самостійно без постійного керівництва, брати відповідальність за власну ініціативу, готовність виявляти проблеми і шукати способи їх розв'язання, використовувати досвід і наявні знання для аналізу нових (екстремальних) ситуацій, здатність співпрацювати з іншими, засвоювати нові знання, здійснювати конструктивну діяльність, виявляти наполегливість та винахідливість, аналізувати соціальні ситуації та групові процеси $[5,40]$.

Для цілеспрямованого формування професійних якостей майбутніх судноводіїв ми пропонуємо враховувати деякі фактори, що дозволять оптимізувати цей процес. Так, для початку, визначаємо ті групи вмінь, які:

a) $є$ необхідні для виконання професійної діяльності; б) є важливим професійним наслідком тренінгнавчання та показником наявності певних професійних якостей [1].

У процесі фахової підготовки, на нашу думку, ми маємо допомогти курсантам виявити, сформувати i використовувати необхідні професійні якості у майбутній професійній діяльності.

Розробка тренінгового курсу формування професійних якостей майбутніх судноводіїв в узагальненому вигляді здійснюється поетапно:

1. Визначення навчальних цілей та очікуваних результатів: визначення знань з професійної галузі; умінь та навичок здійснення квазіпрофесійної діяльності; професійних якостей.

2. Підбір змістовного матеріалу для досягнення навчальних цілей та очікуваних результатів, а також для самостійної роботи: підбір дидактичного матеріалу відповідно до обраних професійних знань, умінь та якостей.

3. Структурування навчального матеріалу відповідно до певних методів навчання: визначення проблемних професійних питань; логічної послідовності навчального матеріалу відповідно методів навчання; врахувати функціональні особливості методів навчання.

4. Розробка тренінгу: розробка плану та програми проведення міждисциплінарного тренінгу.

5. Розробка роздавальних матеріалів для учасників та матеріалів для тренерів: розробка або підбір текстів міні-лекцій; презентацій; матеріалів морської практики; завдань для роботи в малих групах, індивідуальної роботи та для самостійного опрацювання; запитань для мозкового штурму; аналітичних схем для заповнення; запитань для дискусії у малих групах; відеоматеріалів; сценаріїв для проведення рольових ігор; контрольних запитань.

6. Оцінка ефективності і порядок внесення коректив: визначення того, наскільки використовувана система навчання відповідає поставленим цілям і встановленим критеріям ефективності; наскільки правильно встановлено терміни підбиття підсумків навчання; якою мірою підбиття підсумків за звітний період слугує основою для аналізу і внесення коректив, покликаних підвищити ефективність навчання; наскільки чітко документи, що регламентують процес навчання і підвищення рівня сформованості професійних якостей та квазіпрофесійних умінь, визначають порядок унесення змін у використовувані методи навчання.

Переваги обраних методів:

1. Міні-лекція корисна для передачі інформації та закріплення нових знань. 
Наявність прояву професійних якостей у діях майбутніх судноводіїв

\begin{tabular}{|c|c|c|}
\hline Професійні якості & Дії відповідно судна & Дії відповідно екіпажу \\
\hline \multicolumn{3}{|c|}{ Соціологічні } \\
\hline Відповідальність & $\begin{array}{l}\text { Встановлення шляхів руху судна та } \\
\text { дотримання відповідних технічних } \\
\text { вимог } 3 \text { почуттям обов'язку } \\
\text { забезпечення його безпеки (РН 1-13, 16- } \\
20,22,23,27)\end{array}$ & $\begin{array}{l}\text { Утримання власного слова та } \\
\text { зобов'язання до здійснення поступків } \\
\text { (PH 3,6, 13-17, 19-21, 23-26) }\end{array}$ \\
\hline Інтерес до праці & $\begin{array}{l}\text { Прагнення до ефективності } \\
\text { функціонування судна (РН 1, 2, 4, 5, 7- } \\
17,19,20,22,23,25,27)\end{array}$ & $\begin{array}{l}\text { Прояви працелюбності, працездатності } \\
\text { та витривалості у колективній } \\
\text { діяльності екіпажу (РН } 3,6,9,13,14, \\
15,17,19-21,24-26)\end{array}$ \\
\hline \multicolumn{3}{|c|}{ Когнітологічні } \\
\hline Професіональні ЗУН & $\begin{array}{l}\text { Володіння знаннями, уміннями, } \\
\text { навичками в професії на рівні вимог щодо } \\
\text { кваліфікації в технічній діяльності (РН 1- } \\
\text { 13, 15-20, 22, 23, 25, 27) }\end{array}$ & $\begin{array}{l}\text { Володіння знаннями, уміннями, } \\
\text { навичками в професії на рівні вимог щодо } \\
\text { кваліфікації в управлінській діяльності } \\
\text { (РН } 3,6,9,13-16,19-21,23-26)\end{array}$ \\
\hline Комунікативні здібності & $\begin{array}{l}\text { Оцінювання обстановки на судні (РН } 3 \text {, } \\
4,6,13-15,23,27)\end{array}$ & $\begin{array}{l}\text { Орієнтування в незнайомому } \\
\text { соціальному середовищі, відчуття } \\
\text { ситуації та розуміння іншої точки зору } \\
\text { (РН } 3,6,13-15,18-21,23-26)\end{array}$ \\
\hline \multicolumn{3}{|c|}{ Психологічні } \\
\hline Вольові якості & $\begin{array}{l}\text { Терпіння в тривалих та кропітких } \\
\text { професійних справах (PH 1, 2, 4, 9, 13) }\end{array}$ & $\begin{array}{l}\text { Стриманість у прояві почуттів, } \\
\text { витримка та самовладання до членів } \\
\text { екіпажу в професійних ситуаціях (РН } 3 \text {, } \\
6,13-15,18-21,24-26)\end{array}$ \\
\hline $\begin{array}{l}\text { Критичність розуму (вміння } \\
\text { приймати рішення) }\end{array}$ & $\begin{array}{l}\text { Рішуча та своєчасна діяльність в } \\
\text { незвичайних ситуаціях, вміння йти на } \\
\text { ризик (РН 2, 4, 6, 9, 18-20, 22, 25) }\end{array}$ & $\begin{array}{l}\text { Рішучість, здібність діяти самостійно, } \\
\text { своєчасно, сміливо та обгрунтовано в } \\
\text { незвичайних ситуаціях, вміння йти на } \\
\text { ризик (РН 6, 13, 18-21, 24-26) }\end{array}$ \\
\hline Наполегливість & $\begin{array}{l}\text { Наполегливість у досягненні мети, } \\
\text { здібність не відступати від труднощів в } \\
\text { технічній діяльності (РН 1, 2, 4-6, 9, 13, } \\
\text { 17-20, 22, 23, 25) }\end{array}$ & $\begin{array}{l}\text { Наполегливість у досягненні мети, } \\
\text { здібність не відступати від труднощів, } \\
\text { вміння настояти на своєму в } \\
\text { управлінській діяльності (РН } 3,6,13,14 \text {, } \\
\text { 17-21, 24-26) }\end{array}$ \\
\hline \multicolumn{3}{|c|}{ Сенергетичні } \\
\hline Дисциплінованість & $\begin{array}{l}\text { Самодисципліна у виконанні технічної } \\
\text { діяльності (РН 1-13, 15-20, 22, 23, 25, 27) }\end{array}$ & $\begin{array}{l}\text { Додержання припису та розпорядку дня, } \\
\text { зібраність, підтягнутість та } \\
\text { самодисципліна в управлінській } \\
\text { діяльності (РН 3, 13-15, 18-21, 23-26) }\end{array}$ \\
\hline Самоорганізація & $\begin{array}{l}\text { Самоорганізація у дотриманні вимог } \\
\text { професійного технічного середовища (РН } \\
1-13,15-20,22,23,25,27)\end{array}$ & $\begin{array}{l}\text { Самоорганізація у дотриманні вимог } \\
\text { професійного соціального середовища } \\
\text { (PH 3, 13-15, 18-21, 23-26) }\end{array}$ \\
\hline Самокритичність & $\begin{array}{l}\text { Самокритичність у виконанні технічної } \\
\text { діяльності (РН 1-13, 15-20, 22, 23, 25, 27) }\end{array}$ & $\begin{array}{l}\text { Самокритичність у виконанні } \\
\text { управлінської діяльності (РН 3, 13-15, 18- } \\
21,23-26)\end{array}$ \\
\hline Самоконтроль & $\begin{array}{l}\text { Самоконтроль у виконанні технічної } \\
\text { діяльності (РН 1-13, 15-20, 22, 23, 25, 27) }\end{array}$ & $\begin{array}{l}\text { Самоконтроль у виконанні управлінської } \\
\text { діяльності (РН 3, 13-15, 18-21, 23-26) }\end{array}$ \\
\hline \multicolumn{3}{|c|}{ Ноетичні } \\
\hline $\begin{array}{l}\text { Оперативність мисленнєвих } \\
\text { процесів (швидкість мислення) }\end{array}$ & $\begin{array}{l}\text { Чітке орієнтування та дії в мінливих } \\
\text { умовах, швидкість прийняття рішення та } \\
\text { дій у технічній діяльності (РН 2, 4, 6, } 9 \text {, } \\
\text { 18-20, 22, 25) }\end{array}$ & $\begin{array}{l}\text { Вміння швидко, чітко орієнтуватися та } \\
\text { діяти в мінливих умовах, швидкість } \\
\text { прийняття рішення та дій в управлінській } \\
\text { діяльності (РН 6, 13, 18-21, 24-26) }\end{array}$ \\
\hline \multicolumn{3}{|c|}{ Етичні } \\
\hline $\begin{array}{l}\text { Стійкість морально-духовних і } \\
\text { соціально-моральних } \\
\text { орієнтацій }\end{array}$ & $\begin{array}{l}\text { Визнання правових норм та почуття } \\
\text { обов'язку у технічній діяльності (РН 1-13, } \\
15-20,22,23,25,27)\end{array}$ & $\begin{array}{l}\text { Виявлення почуттів обов’язку, } \\
\text { справедливості, совісті та гуманності при } \\
\text { вирішенні професійних ситуацій (РН 3, } \\
\text { 13-15, 18-21, 23-26) }\end{array}$ \\
\hline
\end{tabular}

2. Ситуаційні методи дозволяють краще зрозуміти та навчитися застосовувати в реальних чи гіпотетичних умовах відповідні норми та принципи: широкоформатна ситуація (комплексна проблема, що часто зустрічається у фаховій діяльності і потребує аналізу та оцінки явища та вироблення схеми іï вирішення); мікроситуація (проблема $\epsilon$ менш масштабною, може 
застосовуватися під час дискусії); ситуаціяілюстрація (скерована на опис матеріалу, слугує закріпленню та поглибленню знань, активізації взаємного обміну знаннями та досвідом між учасниками); ситуаційна задача (вимагає не лише аналізу проблеми, але й прийняття рішення та його обгрунтування, часто використовується як завдання для роботи в малих групах); ситуаціяінцидент (спрямована на подолання особистої інертності учасників та вироблення у них адекватних засобів поведінки у стресових та конфліктних умовах).

3. “Мозковий штурм” можна застосовувати як для обговорення проблемних питань всіма учасниками тренінгу, так і під час роботи у малих групах.

4. Робота в малих групах дозволяє учасникам розглянути питання колективно і отримати певну користь (завдання можуть бути однаковими для всіх груп, відрізнятися, але доповнювати одне одного, або бути цілковито різними) [6].

При проведенні тренінгу враховуємо послідовність видів навчальної діяльності (зміна тем і методів навчання), використовуючи практичну модель "руху по колу” (модель Д. Колба):

Цей цикл навчання охоплює чотири послідовні фази: 1)актуалізаціяособистогодосвіду,2)спостереження (аналіз) і обмірковування цього досвіду (рефлексія); 3 ) осмислення отриманих нових знань, їх теоретичне узагальнення (виведення закономірностей, схем); 4) перевірка нових знань і самостійне застосування їх на практиці.

На схему Д. Колба накладаються розроблені змістовні матеріали, для яких вже підібрані методи їх викладання, що сприяє замкненості циклу навчання.

Отже, у досягненні ефективності тренінгу пріоритетними є такі вимоги: урахування базових знань, умінь, навичок (очікуваних результатів); урахування психологічних особливостей учасників (наявність професійних якостей); орієнтування на розв'язання конкретної фахової проблеми; спрямування на досягнення поставлених цілей; використання отриманих результатів.

У кожному разі навчання має допомогти майбутнім судноводіям діяти надійно й компетентно навіть в екстремальних умовах. Курсанти повинні вміти швидко розпізнавати виробничі ситуації, вибудовуючи потім відповідний ланцюг дій, тобто вони повинні індивідуально й компетентно реагувати на типові проблеми відповідно до того, як вони сприйняли ситуацію.

Зрештою, головною метою тренінгу $\epsilon$ очікувана поведінка майбутнього судноводія, не стільки набуття нових знань, скільки формування поведінкових навичок та вмінь за рахунок групової динаміки (тобто проявувідповідних професійних якостей).

Для формування квазіпрофесійного досвіду 3 перспективою майбутнього використання у практичній діяльності необхідно створити умови активної діяльності; орієнтування на практичне використання отриманих знань, їх зв'язок 3 повсякденною діяльністю; опанування навичок командної роботи; обміну досвідом; проектної роботи, що забезпечує закріплення отриманих знань і навичок командної роботи, оцінку ефективності пройденого навчання, виявлення потенціалу, розв'язання актуальних професійних проблем та поліпшення необхідних якостей.

Приклади ситуаційних тренінгових завдань (особливі випадки на судні): “Командування рятувальною шлюпкою”, “Залишення судна”, "Виникнення пожежі на судні”, "Пробоїна в корпусі судна”, “Посадка судна на мілину”, “Раптове виникнення статичного крену на ходу”, “Виявлення сигналів про допомогу”, “Виявлення шлюпки (рятувального плоту) у відкритому морі”, "Падіння людини за борт", "Зупинка головного двигуна судна”, “Вихід з ладу машинного телеграфу судна”, “Вихід $з$ ладу рульового пристрою судна", “Знеструмлення судна”, “Аварійний розлив нафтопродуктів з судна" та інші.

Кожен етап тренінгового курсу повинен мати своє змістовне наповнення, що впорядковується відповідно до певних правил: подання нової інформації та ії обгрунтування відповідно до цілей тренінгу; аналіз складових наданої інформації, виокремлення проблеми, характеристика її впливу на майбутню професійну діяльність; пошуки способів вирішення проблеми, поліпшення чи модернізації діяльності; аналіз запропонованих рішень та вироблення пропозицій щодо їх утілення; на завершальному етапі обов'язковим $\epsilon$ аналіз суб'єктивних вражень учасників та їхнього бачення ефективності отриманих результатів для себе.

Перевагами міждисциплінарного тренінгу є системний характер, комплексність, взаємозв'язок iз різними навчальними дисциплінами фахової підготовки, практична спрямованість поставлених завдань, проблемно-орієнтований характер, розгляд більш широкого кола взаємопов'язаних питань. Курсанти отримують можливість здобувати навички професійної діяльності, проявляються вміння продукувати інновативні розв'язки складних завдань в умовах постійних змін професійного середовища, породжуються 
нові ідеї, з'являється ініціативність, лідерські якості, проявляється здатність до управління екіпажом. Робота в групах активізує процес навчання, робить його цікавим та корисним для реалізації на практиці здобутих знань та вмінь, виявляє та розвиває комунікативні здібності курсантів.

Висновки 3 даного дослідження i перспективи подальших розвідок у даному напрямку. Використання тренінгових форм навчання у формуванні професійних якостей майбутніх судноводіїв здійснюється шляхом цілеспрямованого тренування на основі відповідних стандартів. Необхідною передумовою впровадження тренінгів $€$ визначення групи вмінь, які $€$ важливими для виконання професійної діяльності та показниками наявності певних професійних якостей. Перспективи подальших розвідок у даному напрямку вбачаємо в експериментальній перевірці ефективності впливу тренінгів на формування професійних якостей майбутніх судноводіїв у процесі фахової підготовки.

\section{ЛІТЕРАТУРА}

1. Глікман С. Сугність та структура професійних якостей майбугніх судноводіїв / Світлана Глікман, Наталя Сосницька // Наукові записки. - Випуск 11. - Серія: Проблеми методики фізикоматематичної та технологічної освіти. Частина 4. - Кропивницький: РВВ КДПУ ім. В. Винниченка, 2017. - С. 134-138.

2. Гончаренко С.У. Український педагогічний словник / С.У. Гончаренко. - К.: Либідь, 1997. $375 \mathrm{c}$.

3. Макшанов С.И. Психология тренинга / С.И. Макшанов. - Спб.: Б.в., 1997. - 212 с.

4. Международная конвенция о подготовке и дипломировании моряков и несении вахты 1978 г., измененная конференцией 1995 г. СПб.: ЗАО ЦНИИМФ, 1996. - 551 с.

5. Равен Дж. Компетентность в современном обществе: выявление, развитие и реализация: пер. с англ. / Дж. Равен. Москва: Когито-центр, 2002. C. 40

6. Скляренко І. Педагогічні умови застосування інноваційного підходу в процесі професійної підготовки майбугніх фахівців водного транспорту / Інна Скляренко // Науковий вісник Льотної академії. Серія: Педагогічні науки: зб. наук. пр. / [редкол.: Т.С. Плачинда (голов. ред. та ін.)]. Кропивницький: КЛАНАУ,2017.-Вип. 1.-С.371-376.

7. Словник української мови: в 11 тома. - Том 10, 1979. - С. 245

8. Чернявський В. В. Методичні засади навчання фізики майбутніх фахівців морського та річкового транспорту: автореф. дис. ... д.П.н.: спец. 13.00.02 / В.В. Чернявський. - К. , 2017. $43 \mathrm{c}$.

\section{REFERENCES}

1. Hlikman, S. \& Sosnytska, N. (2017). Sutnist ta struktura profesiinykh yakostei maibutnikh sudnovodiiv [The essence and structure of the professional qualities of future ship drivers]. Scientific notes, vol. 11. Series: Problems of methodology of physical-mathematical and technological education. P. 4. Kropivnitsky: RVV KDPU im. V. Vynnychenka, pp. 134-138. [in Ukrainian].

2. Honcharenko, S. (1997). Ukrainskyi pedahohichnyi slovnyk [Ukrainian pedagogical dictionary]. Kyiv: Lybid, 375 p. [in Ukrainian].

3. Makshanov, S. (1997). Psikhologiya treninga [Psychology of training]. Saint Petersburg, 212 p. [in Russian].

4. Mezhdunarodnaya konventsiya o podgotovke i diplomirovanii moryakov i nesenii vakhty $1978 \mathrm{~g}$., izmenennaya konferentsiey 1995 g. (1996). [International convention on the preparation and certification of seafarers and watchkeeping, 1978, amended by the 1995 conference]. Saint Petersburg: ZAO TSNIIMF, 551 p. [in Russian].

5. Raven, Dzh. (2002). Kompetentnost $v$ sovremennom obshchestve: vyyavlenie, razvitie $i$ realizatsiya: per. $s$ angl. [Competence in modern society: identification, development and implementation: translation from english]. Moscow: Cogito-center, p. 40. [in Russian].

6. Skliarenko, I. (2017). Pedahohichni umovy zastosuvannia innovatsiinoho pidkhodu $\mathrm{v}$ protsesi profesiinoi pidhotovky maibutnikh fakhivtsiv vodnoho transportu [Pedagogical conditions of application of innovative approach in the process of professional training of future specialists in water transport]. Scientific flyer of the Flight Academy. Series: pedagogical sciences: a collection of scientific works. Kropivnitsky: KLA NAU, vol. 1, pp. 371-376. [in Ukrainian].

7. Slovnyk ukrainskoi movy (1979). [Dictionary of the Ukrainian language]. Vol. 10, p. 245. [in Ukrainian].

8. Cherniavskyi, V. (2017). Metodychni zasady navchannia fizyky maibutnikh fakhivtsiv morskoho ta richkovoho transportu [Methodical principles of teaching physics of future specialists in sea and river transport]. Extended abstract of Doctor's thesis. Kyiv, 43 p. [in Ukrainian].

Стаття надійшла до редакції 27.04.2018 